Article

\title{
Evaluation of Agricultural Water Pricing in an Irrigation District Based on a Bayesian Network
}

\author{
Xiaotong Zhu ${ }^{1,2}$, Guangpeng Zhang ${ }^{1,2}$, Kaiye Yuan ${ }^{1,2}$, Hongbo Ling ${ }^{1, *}$ and Hailiang $X u^{1}$ \\ 1 State Key Laboratory of Desert and Oasis Ecology, Xinjiang Institute of Ecology and Geography, \\ Chinese Academy of Sciences (CAS), Urumqi 830011, China; zhuxiaotong16@mails.ucas.ac.cn (X.Z.); \\ zhangguangpeng2009@163.com (G.Z.); yuankaiye91@163.com (K.Y.); xuhl@ms.xjb.ac.cn (H.X.) \\ 2 University of Chinese Academy of Sciences, Beijing 10049, China \\ * Correspondence: linghongbo0929@163.com; Tel.: +86-186-9032-4733
}

Received: 19 April 2018; Accepted: 9 June 2018; Published: 12 June 2018

\begin{abstract}
In recent years, the large-scale development of land and water resources has led to a conflict between water supply and demand. Especially in arid regions, fragile ecosystems and continuous farmland expansion have threatened the ecological and social security of river basins. Therefore, it is urgent to propose scientific and reasonable water resource management models to alleviate this conflict. Based on the principle of "the strictest water resource management measures" for river basin water resources, this study has taken Heshuo County, Xinjiang as the research object, using a full-cost method to determine agricultural water prices for the irrigation district at $0.35 \mathrm{RMB} / \mathrm{m}^{3}$ and $1.4 \mathrm{RMB} / \mathrm{m}^{3}$. With the participation of stakeholders and experts, current water rights trading and management systems were analyzed by a Bayesian network (BN) model. In addition, the impact of water-pricing policy on farmers' planting behavior was also quantified. The results indicated that an increase in water prices can effectively reduce agricultural water consumption for irrigation, but it would also induce negative externalities involving groundwater (GW) preservation and farmers' income. A water resource management model mainly directed by water-pricing policy, and supplemented by GW protection and agricultural subsidy policies, could effectively regulate farmers' water-use behavior, guarantee farmers' income, and protect GW. This study provides a successful management approach for coordinating the relationship between agricultural water resources and the ecological environment in an arid basin watershed and promoting the efficient use of agricultural water resources in irrigated areas.
\end{abstract}

Keywords: water pricing; water use efficiency; water resource management; Bayesian network

\section{Introduction}

Water is not the only basic condition for human beings to survive and develop, it is also an essential natural and strategic resource that sustains ecosystem functions and supports the development of economic systems [1-3]. Due to climate change and the unreasonable extraction and use of water resources, water shortages have become a global problem. These shortages have severely affected people's daily life and hindered global economic development [4-6]. The increasing cultivation of reclaimed land and waste of agricultural water resources are major causes of water shortages $[7,8]$. Deininger et al. [9] found that global arable land expanded at an average rate of $3.8 \times 10^{6} \mathrm{hm}^{2} / \mathrm{a}$ between 1961 and 2007, and that arable land increased at an average rate of $5 \times 10^{6} \mathrm{hm}^{2} / \mathrm{a}$ in developing countries, mainly in South Africa, Latin America, and East Asia. Taking the Tarim River basin, Xinjiang, as an example, arable land along the main stream increased by 51.95\% from 1990-2000 to 2000-2010 [10]. The arid climate and the continuous expansion of arable land have caused the ecological water that is needed to protect desert riparian forest vegetation in the upstream and 
midstream reaches to be crowded out by agricultural water demand, resulting in drastic decreases in downstream water supply and intensifying desertification. These developments have constrained the sustainable socio-economic development of the river basin. Managing the conflict between agricultural and ecological water use in a scientific manner has become a keystone of water resource management for arid regions.

Water resource management models centered on water price have consistently attracted the attention of governments all around the world [11,12]. The use of water rights trading and water-pricing policy for the macro-control of the market has become an effective tool to alleviate the conflict between ecological protection and agricultural production, thus solving the problem of water resource allocation in river basins [13]. Determining a water-pricing standard and evaluating its utility are key to establishing an appropriate price, which is directly related to the scientific validity, feasibility, and effectiveness of basin water resource arrangements. Setting water prices low will reduce farmers' consciousness of water savings, resulting in a lack of water supply and income to suppliers. On the other hand, setting water prices high has an obvious impact on agricultural production and farmers' incomes [14,15]. Due to the variations in agricultural performance and water-pricing models among nations [16], determining optimal irrigation water pricing remains a topic of debate among researchers. One reason for this is that irrigation water has characteristics of being both a quasi-public property and a general commodity, meaning that a price formulation process should combine farmers' willingness and ability to pay, the production cost of water resources, marginal costs, market demand, and other factors [17].

For arid regions, water resources are the most important environmental factor guaranteeing the structural integrity and functional stability of the river basin ecosystem [18,19]. Water-pricing calculations must consider both resource and environmental costs to reflect the scarcity characteristics of water resources [20]. The traditional water-pricing calculation method ignores the value of water resources, whereas the full-cost method determines water pricing based on the value of water resources by charging a water resource fee to ensure hydrographic environment transport capability [21,22]. Many water-pricing studies have been conducted in recent years. Mann [23] studied the relationship between water-supply pricing and water consumption through time-series data, and concluded that consumers should pay the full cost of the benefits that they obtain. Kim [24] studied water-supply services through marginal-cost pricing, and concluded that marginal-cost pricing could maximize social welfare compared with average-cost pricing. Riesgo et al. [25] studied the impact of water-pricing changes on the agricultural planting structure using a water-pricing estimation model. Moore et al. [26] estimated the relationship between irrigation water amount and water pricing by means of meteorological analysis. Dinar et al. [27] developed a water distribution plan for different social groups based on water-pricing policy. Berbel et al. [28] used linear programming to analyze the impact of an increase in water prices on farmers' planting structure and water-use behavior. Giacomo et al. [29] analyzed the relationship between water prices and farmers' incomes by comparing different water-pricing methods. When summarizing these previous studies, it becomes apparent that the Bayesian network (BN) model has been little used to estimate the impact of water-pricing policy on farmers. In contrast, the BN model is widely used in various fields such as natural resource management, groundwater (GW) protection, and ecological vulnerability assessment $[30,31]$. If the knowledge structure in the human brain can be simulated to build a topological relationship among variables, scenario simulations can then be performed to determine the optimal management strategy. Moreover, the BN model reflects the probabilistic relationships among data in the entire database, and it can still be accurate, even if parts of the data are missing. Another advantage of the BN model is that data acquisition is flexible, accommodating stakeholder knowledge, expert estimation, empirical data, and other contributions [32-34].

Therefore, this study has used the full-cost and BN models to calculate and evaluate water-pricing policy for the purpose of coordinating the relationship between agricultural and ecological water use in arid basin watersheds. The models provide theoretical support for mitigating water scarcity at the river basin level. The framework presented in this paper can be divided into stages as follows: 
(1) using the collected information and combining the goal of cropland retirement under the restriction of "the strictest water resource management measures" to calculate water price; (2) with stakeholders' participation and expertise, constructing the BN model; (3) analyzing the irrigation actions of farmers using the BN model; and (4) discussing the challenges and opportunities for the BN model.

\section{Materials and Methods}

\subsection{The Full-Cost Model}

Water prices as calculated by the full-cost model are mainly composed of engineering, resource, and environmental water prices. The resource water price is the value of the water resource in the process of being used by farmers, which reflects the property right and commodity aspects of the water resource. The environmental water price is economic compensation for the negative external effect of agricultural irrigation activities on the environment. The calculation formula of the full-cost model is:

$$
W_{1}=\sum\left(\frac{Z+D}{Q_{1}}+\frac{Y+R+L}{Q_{2}}\right)+\frac{C_{1}+C_{2}}{Q_{3}}
$$

where $W_{1}$ represents the full-cost water price, $Z$ is the annual water supply production cost of hydraulic engineering, $D$ is the annual water supply cost for hydraulic engineering, $Y$ is the management cost, $R$ is the staffing cost, $L$ is the maintenance cost, $Q_{1}$ is the annual average water supply, $Q_{2}$ is the terminal water supply, $C_{1}$ is the water cost per unit area for agricultural irrigation waste, $C_{2}$ is the environmental cost per unit area for agricultural planting activity, and $Q_{3}$ is the cost per unit of irrigation water [35].

The marginal benefits determine farmers' willingness to plant. Economic water pricing was introduced to achieve the government's goal of farmland abandonment; the formula is:

$$
W_{2}=\sum_{i=1}^{n} \frac{C_{i} V_{i}}{Q_{3} V}
$$

where $W_{2}$ represents the economic water price, $C_{i}$ is the economic benefits produced per unit area by planting crop $i, V_{i}$ is the share accounted for by crop $i$ in the area of cultivated land that must be abandoned, $Q_{3}$ is the agricultural irrigation volume per unit area, and $V$ is the area of abandoned farmland. The water price in the irrigated area is composed of a basic and a composite water price. The formula is:

$$
\begin{gathered}
P_{1}=W_{1} \\
P_{2}=W_{1}+W_{2}
\end{gathered}
$$

where $P_{1}$ represents the basic water price, $P_{2}$ is the composite water price, $W_{1}$ is the full-cost water price, and $W_{2}$ is the economic water price.

\subsection{The BN Model}

The BN model is composed of two parts: the network structure and network parameters, which correspond to qualitative and quantitative descriptions of the problem [36-38]. The network structure $H$ is a directed acyclic graph (DAG) consisting of a set of node variables, $K\left(K=\left\{k_{1}, k_{2}, \ldots k_{n}\right\}\right)$ and a set of directed edges, $H\left(H=\left\{k_{i} k_{j}, k_{i} k_{j}, \in K\right\}\right)$. The network structure is represented as:

$$
S=(K, H)
$$

The network parameter $P$ is a conditional probability table (CPT) of variable nodes representing the intensity of the causal effect between variables. The formula is:

$$
P=\left\{P\left(K_{1}, K_{2}, \ldots, k_{i-11}\right)\right\}, K_{i} \in K
$$


A BN model can be expressed as:

$$
B=(S, P)=(K, H, P)
$$

If $K_{p i}$ is used to represent the parent node set of variable $K_{i}$, the joint probability distribution of $K$ is:

$$
P(K)=P\left(K_{1}, K_{2}, \ldots, K_{n}\right)=\prod_{i-1}^{n} P\left(V_{i} \mid V_{p i}\right)
$$

\subsection{Construction of the $B N$}

The BN construction process mainly follows the guidelines proposed by Bromley [39]. The first step, before constructing the model, is to identify the research questions and stakeholders that may be involved. The second step involves discussions with stakeholders to determine the variables related to the study. Since each variable in the system has a different meaning, to facilitate network construction, the variables are divided into six categories according to their functions, as shown in Table 1 . In the third step, a test $\mathrm{BN}$ is constructed with stakeholders, and the research questions are combined with their contributions to revise the trial network until it becomes consistent, logical, and able to reach the desired goals. In the fourth step, the status of the network nodes is determined according to the principle of minimization, and relevant data on topics such as the county's social economy, water conservancy projects, and agriculture are collected, combining expertise and farmers' experience to fill the CPT of the nodes. In the final step, the sensitivity of the network variables is analyzed, and the BN is compiled to make decisions. The impact of water prices on farmers' planting behavior was analyzed through discussion with local management departments, stakeholders, and experts. Twenty-six main variables were finally determined. By analyzing the relationships among the variables, a DAG of the BN was constructed, as shown in Figure 1.

\begin{tabular}{|c|c|c|}
\hline Category & Description & Variable \\
\hline Objectives & $\begin{array}{l}\text { The variables that we hope to affect } \\
\text { through scenarios }\end{array}$ & $\begin{array}{l}\text { farmland reduction, ecological } \\
\text { service value (ESV) }\end{array}$ \\
\hline Interventions & $\begin{array}{l}\text { The variables that we need to } \\
\text { implement to achieve the objectives }\end{array}$ & $\begin{array}{l}\text { water price, groundwater }(\mathrm{GW}) \\
\text { policy, subsidize policy, land-use } \\
\text { pattern (LUP) }\end{array}$ \\
\hline Intermediate Factors & $\begin{array}{l}\text { The variables that link objectives and } \\
\text { interventions }\end{array}$ & $\begin{array}{l}\text { change plant structure (action1), } \\
\text { water-saving techniques (action2), } \\
\text { drill well (action3), irrigation } \\
\text { water amount, technical cost, } \\
\text { drilling cost, yield, irrigation cost, } \\
\text { operating cost, income, farming } \\
\text { cost, profit, ESV equivalent }\end{array}$ \\
\hline Controlling factors & $\begin{array}{l}\text { The variables that we cannot control } \\
\text { but influence the system }\end{array}$ & $\begin{array}{l}\text { rainfall, market price, the } \\
\text { economic value of farmland }(\mathrm{EV})\end{array}$ \\
\hline Implementation factors & $\begin{array}{l}\text { The variables that directly affect } \\
\text { whether an intervention might } \\
\text { be successful }\end{array}$ & acceptance, GW level \\
\hline Additional impacts & $\begin{array}{l}\text { The variables that changed due to the } \\
\text { interventions but do not affect other } \\
\text { variables in the system }\end{array}$ & not used \\
\hline
\end{tabular}

Table 1. Categories of variables in the Bayesian network (BN). 


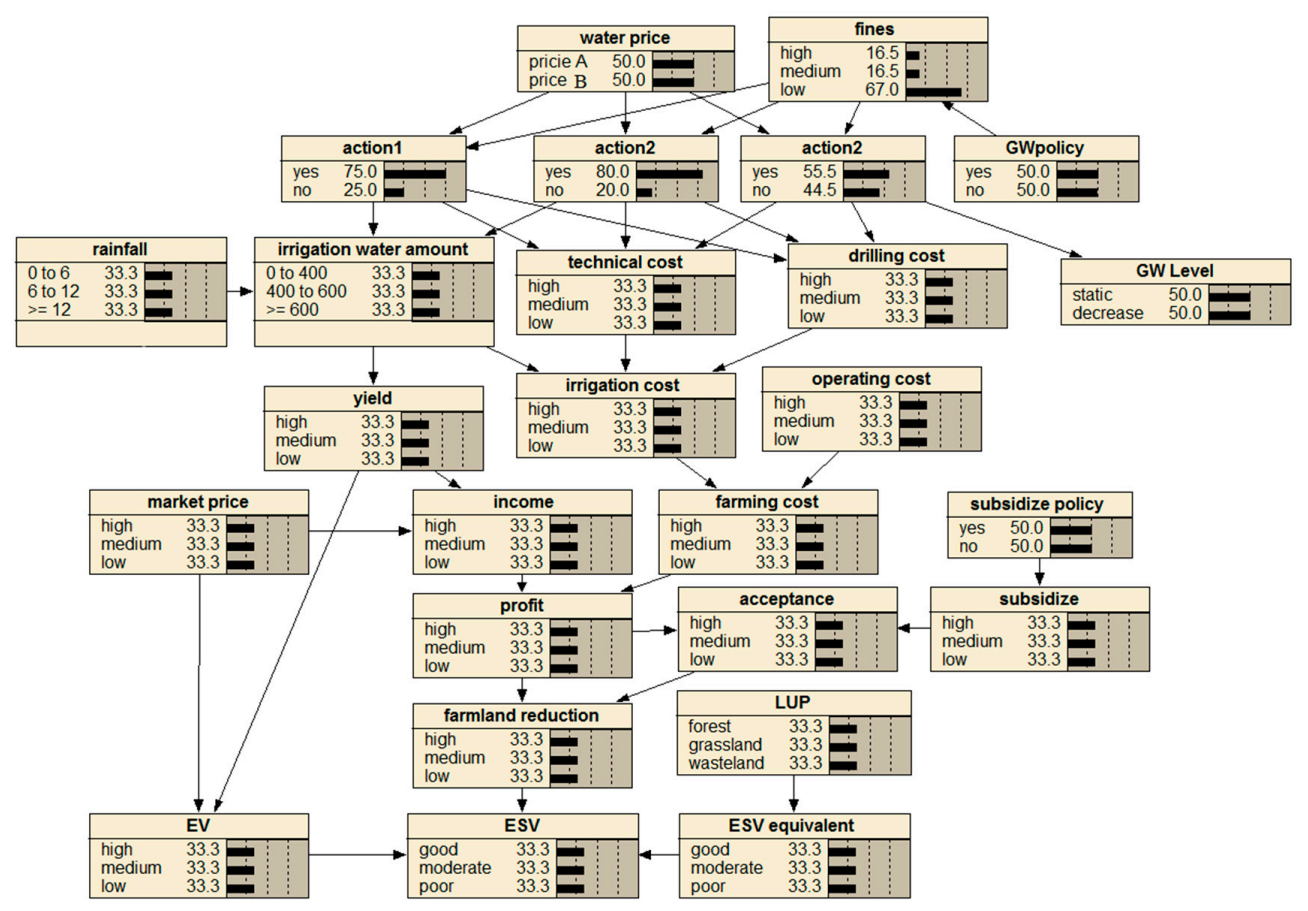

Figure 1. Participatory BN model simulation with elicited conditional probability table (CPT).

\subsection{K-Fold Cross-Validation}

With the complexity of the system, the results of the BN model diagnosis may be vulnerable to overfitting and exaggerations of forecast quality [40]. To assess the overall performance of a model, its predictive accuracy should be tested, which can be accomplished through $K$-fold cross-validation [41]. The training data are divided into $K$ folds on average; each group of data is taken as a verification set, and the remaining $(K-1)$ data subsets are used as a training set. By using the training set to fill the $\mathrm{CPT}$ of the $\mathrm{BN}$ and using the verification set through probabilistic reasoning, the state with the highest probability can be chosen as the predicted value, and the predicted and actual values can be compared to determine the error rate of the BN model [42]. The formula is:

$$
\text { Error }=\frac{\sum \text { Case }_{f}}{\sum \text { Case }_{f}+\sum \text { Case }_{t}}
$$

where $\sum \mathrm{Case}_{f}$ represents the number of training data points for which the predicted value is different from the actual value, and $\sum \mathrm{Case}_{t}$ represents the number of training data points for which the predicted value is the same as the actual value. Error represents the error rate of the BN model.

This study divided the training data into five groups, taking the first group as a verification set. Table 2 shows that the error rate of the first group was $17 \%$. Similarly, Table 3 shows the error rates of the other verification groups. The average error of the model was calculated as $15.4 \%$, indicating that overall model performance was good.

Table 2. Validation results of the first group (target variable: farmland reduction).

\begin{tabular}{cccc}
\hline \multicolumn{3}{c}{ Predictive Value } & Practical Value \\
\cline { 1 - 3 } High & Medium & Low & \\
\hline 32 & 5 & 0 & High \\
2 & 18 & 3 & Medium \\
0 & 7 & 33 & Low \\
\hline
\end{tabular}


Table 3. Summary of error rate results for five groups.

\begin{tabular}{cccccc}
\hline Group & $\mathbf{1}$ & $\mathbf{2}$ & $\mathbf{3}$ & $\mathbf{4}$ & $\mathbf{5}$ \\
\hline Error rate & $17 \%$ & $19 \%$ & $21 \%$ & $9 \%$ & $12 \%$ \\
\hline
\end{tabular}

\subsection{Data Collection and Processing}

The data for calculating water prices were obtained mainly from policy documents, scientific literature, and official statistics. Construction of the BN model mainly involved expert interviews and stakeholder participation. The data to populate the CPT of the nodes came mainly from expert knowledge, stakeholder experience, and Xinjiang statistical yearbooks. Experts specializing in water resource management and ecological restoration came from research institutes and universities in Xinjiang. Stakeholders included the county water department and local farmers. The data from Xinjiang statistical yearbooks included the area of irrigation water consumption from 2015 to 2017, agricultural population, the area of major crops, and other variables.

The Netica software was used for data processing. Netica is a powerful BN tool for the graphical modeling and visual display of probabilistic parameters, which can learn the parameters of the BN and provides three algorithms, including the incorp case file, expectation maximization (EM), and gradient descent. According to the simulation scenario, the BN probability was automatically updated by entering the node evidence information into the Netica software.

\section{Case Study}

\subsection{Study Area}

As shown in Figure 2, Heshuo County is located in the central area of the Xinjiang Uyghur Autonomous Region in northwestern China $\left(40^{\circ} 25^{\prime} \mathrm{N}-42^{\circ} 47^{\prime} \mathrm{N}, 84^{\circ} 41^{\prime} \mathrm{E}-88^{\circ} 22^{\prime} \mathrm{E}\right)$, which belongs to the warm temperate climatic zone. The annual temperature is $8.6^{\circ} \mathrm{C}$. The total area of cultivated land is $36,168.43 \mathrm{hm}^{2}$, with a population of $6.57 \times 10^{4}$, of which the agricultural population is $1.6 \times 10^{4}$. The main agricultural areas are located on the floodplains, and the fluvial plain of the Qingshui, Quhui, and Washitala rivers. Agriculture occupies an important position in the regional economic development of Heshuo County as a basic and strategic industry. In recent years, low economic efficiency and a high consumption of agricultural water resources have led to a continuous reduction in the proportion of water used for agriculture, and the conflict between water supply and demand has become increasingly sharp.

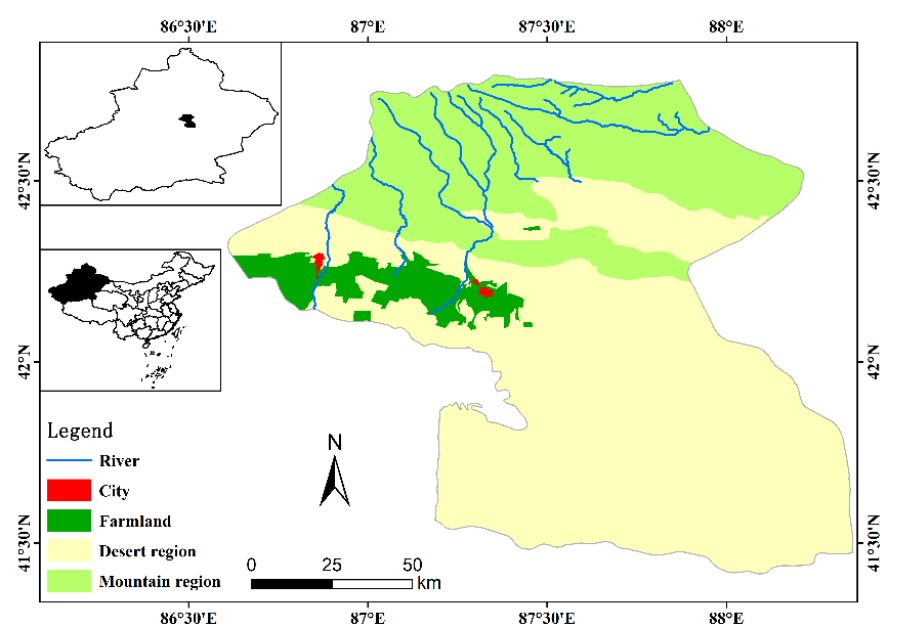

Figure 2. Map of the study region. 
To alleviate the conflict between water supply and demand in the basin, the Xinjiang Tarim River Basin Authority has formulated the "strictest water resource management measures" for water resources in the basin, which require that all areas strictly control the total amount of water resources used, and define water quality and the planning approach to prime farmland. According to the "strictest water resource management measures" and water quantity control requirements, Heshuo County must take $1.574 \times 10^{4}$ hectares of land out of production. The challenge of convincing peasants to reduce their cultivated land intentionally has become a problem that the government urgently needs to solve.

This study chose Heshuo County as a typical county, and used the water-pricing policy to improve the county's water rights allocation and trading system under the control of "the strictest water resource management measures". By using the BN model to assess the impact of water pricing on farmers' planting behavior, this study has provided an optimal water resource management approach based on water rights trading to realize the coordinated development of economic, social, and ecological systems in river basins. At the same time, this study has also provided a new method to solve the problem of agricultural water resources in developing countries and the rest of the world.

\subsection{Scenario Development}

As shown in Table 4, four scenarios were designed in the BN. The interventions variable in the table sets the probability of each state of the variable node to $100 \%$ respectively as a prerequisite for scenario simulation. In Scenario 1, the Netica software was used to enter information into the water-pricing nodes in the BN model, and set the probabilities of water-pricing nodes A and B to observe the changes in the probability values of other nodes to simulate the impact of a single water-pricing policy on farmers' planting behavior. Scenario 2 introduced a GW policy and imposed fines on farmers who privately exploited GW based on Scenario 1, which entered information into the GW node to observe the changes in the probability values of other nodes, and simulate the impact of water prices on farmers' planting behavior under the GW policy. Scenario 3 introduced an agricultural subsidy policy based on Scenario 2 and provided certain economic compensation for farmers who were willing to take cultivated land out of production, simulating the impact of water prices on farmers' planting behavior under the GW policy, and the agricultural subsidy policy. Scenario 4 was used to simulate the impact of water pricing on the value of land ecological services.

Table 4. The target variable under different water pricing scenario.

\begin{tabular}{ccl}
\hline Scenario & Intervention Variables & \multicolumn{1}{c}{ Target Variable } \\
\hline Scenario 1 & water price & $\begin{array}{l}\text { action1, action2, action3, irrigation cost, income, } \\
\text { farmland reduction, GW level, irrigation water amount }\end{array}$ \\
\hline Scenario 2 & water price, GW policy & $\begin{array}{l}\text { action1, action2, action3, GW level, income, } \\
\text { irrigation cost, acceptance, farmland reduction }\end{array}$ \\
\hline Scenario 3 & $\begin{array}{c}\text { water price, GW policy, } \\
\text { subsidize policy, }\end{array}$ & acceptance, farmland reduction \\
\hline Scenario 4 & $\begin{array}{c}\text { water price, GW policy, } \\
\text { subsidize policy, LUP }\end{array}$ & ESV \\
\hline
\end{tabular}

\section{Results}

\subsection{Calculation of Water Pricing}

Table 5 shows the relevant data for the water-pricing calculation. The management and maintenance costs include the management and maintenance costs for hydraulic engineering, and the labor cost. According to Qiong [43], the negative external cost of planting cotton per unit area in Xinjiang was $2144.9 \mathrm{RMB} / \mathrm{hm}^{2}$, of which the environmental cost $C_{2}$ was $2722.1 \mathrm{RMB} / \mathrm{hm}^{2}$, and the water resource $\operatorname{cost} C_{1}$ was $31,422.8 \mathrm{RMB} / \mathrm{hm}^{2}$. The income from planting cotton per unit area in 2016 
from the agricultural sector in the main producing areas was $7846.5 \mathrm{RMB} / \mathrm{hm}^{2}$. Using the water-pricing calculation formula, the final agricultural irrigation price for basic farmland under the control of "the strictest water resource management measures" was $0.35 \mathrm{RMB} / \mathrm{m}^{3}$, and the irrigation water price outside the control of "the strictest water resource management measures" was $1.4 \mathrm{RMB} / \mathrm{m}^{3}$.

Table 5. The data for water pricing calculation.

\begin{tabular}{ccccc}
\hline $\begin{array}{c}\text { Agricultural } \\
\text { Population }\left(\mathbf{1 0}^{3}\right)\end{array}$ & $\begin{array}{c}\text { The Government's Goal } \\
\text { of Abandoned } \\
\text { Farmland }\left(\mathbf{1 0}^{\mathbf{3}} \mathbf{~ h m}^{\mathbf{2}}\right)\end{array}$ & $\begin{array}{c}\text { Annual Average } \\
\text { Water Supply }\left(\mathbf{1 0}^{\mathbf{3}} \mathbf{~ m}^{\mathbf{3}}\right)\end{array}$ & $\begin{array}{c}\text { Overheard and } \\
\text { Maintenance } \\
\text { Expenses (10 } \mathbf{~ R M B )}\end{array}$ & $\begin{array}{c}\text { Annual Water Supply } \\
\text { Cost (10 }\end{array}$ \\
\hline 16.545 & 6.8 & 5000 & 1173.8 & 1174.8 \\
\hline
\end{tabular}

\subsection{Sensitivity Analysis}

As the most effective method for evaluating model performance, sensitivity analysis is crucial to examine the impact of uncertainties [44,45]. Sensitivity analysis can be used to discover the factors that have an important influence on the BN target variables and analyze and measure the degree of impact on and sensitivity to the target variables. The results can be used as a reference for tuning the model parameters and studying the effect of parameter changes on the robustness of the model output $[46,47]$. The two most commonly used sensitivity analysis methods are the sensitivity function, which describes an output probability of interest as a function of one or more network parameters, and the quantification of the closeness of the probability density function of the perturbed model and the probability density function of the original model. The built-in sensitivity function of the Netica software was chosen for sensitivity analysis in this study because it could calculate the influence of model parameter changes more easily than the second method, which would need to introduce coefficients for quantification.

Figure 3 shows the results of the sensitivity analysis. The left side of the coordinate axis represents the mutation information of the node variable, and the right side represents the variance of beliefs. Higher values of mutation information indicate that the target variable is more sensitive to the node variables. According to Figure 3, the variable that is most sensitive to farmland reduction is irrigation cost, the variable that is most sensitive to GW level is action3, and the variable that is most sensitive to acceptability and ecological service value (ESV) is profitability, which indicates that the marginal profit generated by planting is the main factor affecting farmers' willingness to plant and accept water prices. Since the land is artificially regulated, the ESV of farmland is also affected by the profitability of planting. A direct relationship also exists between GW preservation and whether farmers are drilling wells. This also explains the rationality of introducing a water-pricing policy, GW policy, and agricultural subsidy policy to regulate farmers' planting behavior. 


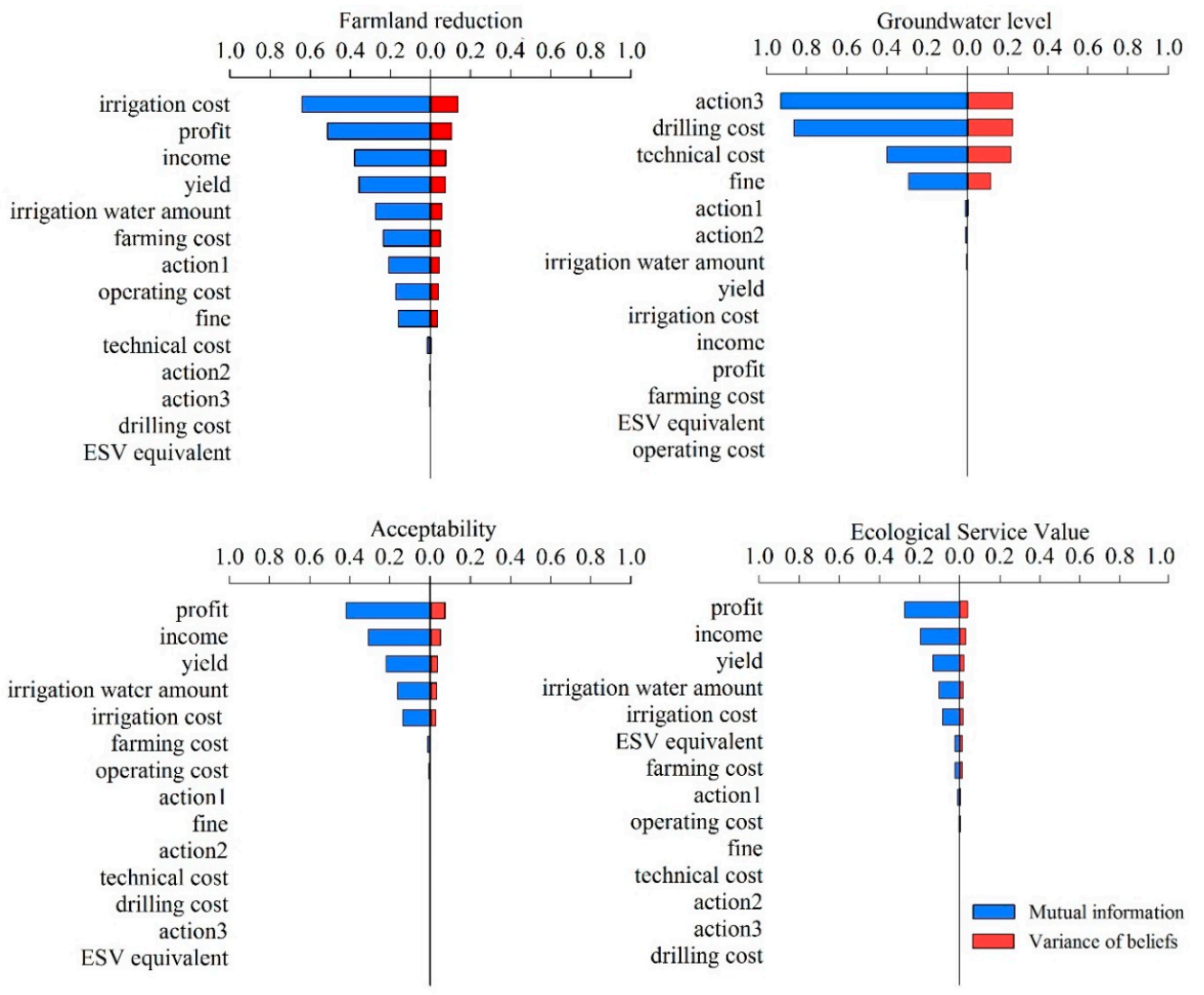

Figure 3. Sensitivity analysis for a BN model. The length of the blue bars represent each sensitivity variable in the figure as a measure of the influence of that variable on the target nodes. The larger the number is, the more sensitive the influencing variable is on the target nodes.

\subsection{Scenario Simulation}

\subsubsection{Single Water Pricing Scenario}

In the course of planting activities, farmers usually adopt action1 (converting high-water crops such as cotton into low-water crops such as wheat) and action2 (sprinkler irrigation and drip irrigation), as well as action3 (improving water efficiency and increasing the water amount to meet irrigation needs). Figure $4 \mathrm{~A}$ shows that with an increase in water prices, the probabilities of farmers adopting action 1 , action 2 , and action 3 have increased by $13.2 \%, 4.9 \%$, and $0.8 \%$, which indicate that water prices have no obvious effect on encouraging farmers to adopt water-saving technology. The probabilities of farmers adopting drilling under two different water prices are $71.9 \%$ and $72.7 \%$, respectively. It shows that drilling a well is still the main means for farmers to meet water demand. Figure $4 \mathrm{~B}$ shows that the probability of irrigation water consumption is concentrated in the middle and high range $(16.6 \%$ and $83.4 \%$ ) when the water price is $\mathrm{A}$, whereas they are mainly concentrated in the middle-low range $(27.2 \%$ and $72.8 \%)$ when water pricing is $\mathrm{B}$. These results suggest that raising water price can reduce the consumption of agricultural irrigation water. Figure $4 \mathrm{c}-\mathrm{f}$ show that when water pricing is $\mathrm{A}$, the probability of high irrigation costs for farmers and a farm's income are high, reaching the government's goal of farmland abandonment, and the GW level decrease is $2.92 \%, 67.3 \%, 16.5 \%$, and $73.5 \%$, respectively. Meanwhile, when water pricing is $\mathrm{B}$, the probability is $71 \%, 8.84 \%, 6.27 \%$, and $68.9 \%$, respectively. The results indicate that higher water prices increase farmers' irrigation costs, leading to lower planting profitability and significantly increasing the probability of farmland abandonment. However, in both cases, GW supplies are facing a high probability of depletion, meaning that a single water-pricing policy is not desirable. 

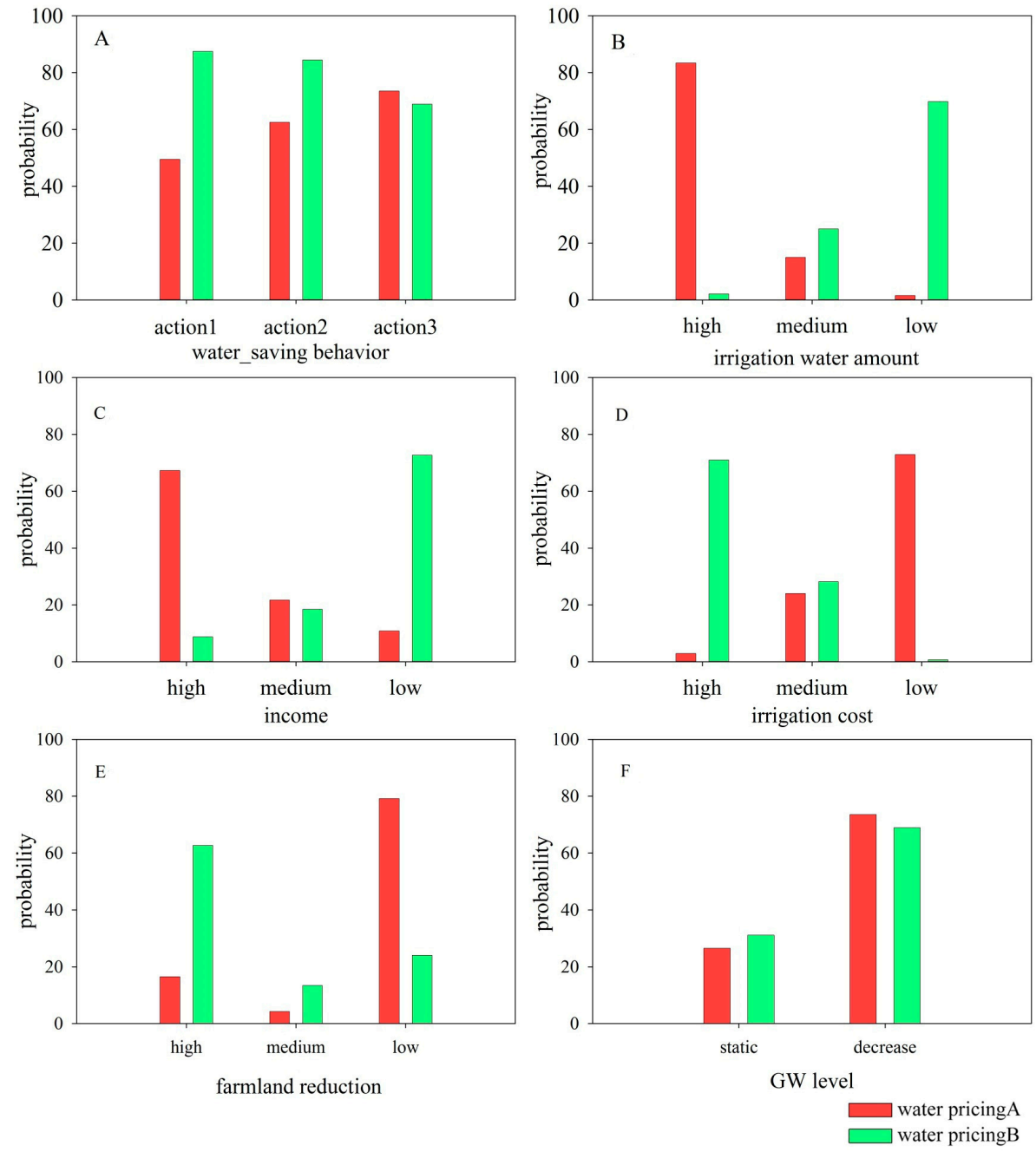

Figure 4. The effect of water pricing on farmers' planting behavior. (A) represents the probability of farmers using different water-saving methods under different water pricing; (B) represents the amount of irrigation water used by farmers under different water pricing; (C) represents farmers' income levels under different water pricing; (D) represents the irrigation cost for farmers under different water pricing; (E) represents the reduction of arable land for farmers under different water pricing; (F) represents GW levels under different water pricing.

\subsubsection{Water Pricing Scenario Based on GW Policy}

According to Figure 5A, with the increase of GW extraction, when the water price is A, the probabilities of farmers adopting action 1 and action 2 increase by $7 \%$ and $10 \%$, respectively. When the water price is $B$, the probabilities are $43 \%$ and $28 \%$, respectively. When the water price is $A$, the probability of farmers adopting action 3 drops by $70 \%$, while the probability is $88 \%$ when the water price is B. Clearly, GW policy can effectively reduce farmers' drilling activities; at the same time, under the GW policy, raising water prices can effectively promote water-saving behavior among farmers. According to Figure 5B, when the GW fine is low, the probability that the GW level will remain static is $5 \%$ in both water-pricing schemes. However, when the GW fine is high, the probabilities are $80 \%$ and $98 \%$, which indicate that only GW protection measures with high penalties can ensure GW preservation. According to Figure $5 \mathrm{C}, \mathrm{D}$, when the water price is $\mathrm{A}$, lower irrigation costs (probability of $64.7 \%$ ) make it possible for farmers to meet water demand even if they do not engage in well-drilling, and have a higher income (probability of $62.6 \%$ ). However, when the water price is $\mathrm{B}$, higher irrigation costs (probability of $73.7 \%$ ) reduce farmers' income (probability of $75.2 \%$ ). When GW mining penalties 
are high, in the face of excess water demand, farmers can either choose to pay high water prices or abandon farmland. According to Figure $5 \mathrm{E}, \mathrm{F}$, when the water price is $\mathrm{B}$, the probabilities of the government achieving its goals of farmland abandonment and farmer acceptance of policies are $46.5 \%$ and $67.5 \%$, which are increases of $46.5 \%$ and $21 \%$, respectively, compared with when the water price is A. This shows that water pricing is an important tool to persuade farmers to intentionally abandon farmland. However, this scenario is prone to policy failure because of low acceptance by farmers.
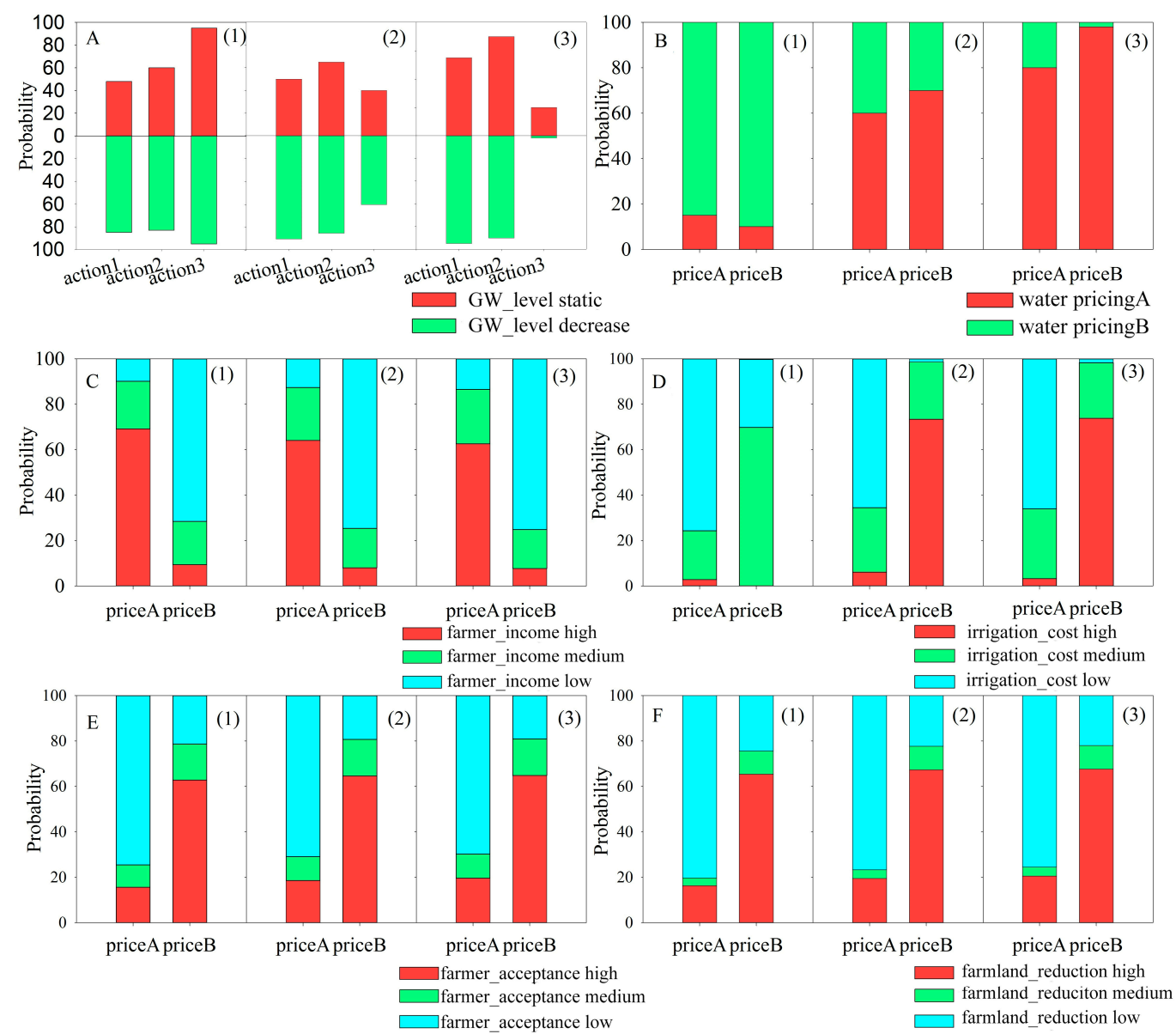

Figure 5. The impact of water pricing policy based on GW policy on farmers' planting behavior. (A) (1)-(3) represent the probability of farmers using different water-saving methods under different water pricing when GW mining fines are low, medium, and high respectively; (B-F) (1)-(3) respectively represent the probability of GW safety, a farmer's income level, a farmer's irrigation cost, the degree of acceptance of a farmer to abandon farmland, and the reduction of arable land under different water pricing when GW mining fines are low, medium, and high, respectively.

\subsubsection{Water Pricing Scenario Based on Multi-Policy Intervention (Scenario 3)}

An agricultural subsidy policy was introduced in Scenario 3 on the basis of Scenario 2 to provide economic compensation to farmers who were willing to abandon farmland. According to Figure $6 \mathrm{~A}$, with the increase of the agricultural subsidy, the probability of accepting government policy and supporting the government goal of farmland abandonment for farmers is $71.3 \%$ and $77.7 \%$ when the water price is $\mathrm{B}$, whereas the probability is $25.6 \%$ and $65 \%$, respectively, when the water price is A. The results of this scenario indicate that water-pricing policy is effective in regulating farmers' planting behavior under agricultural subsidy and GW policies. 

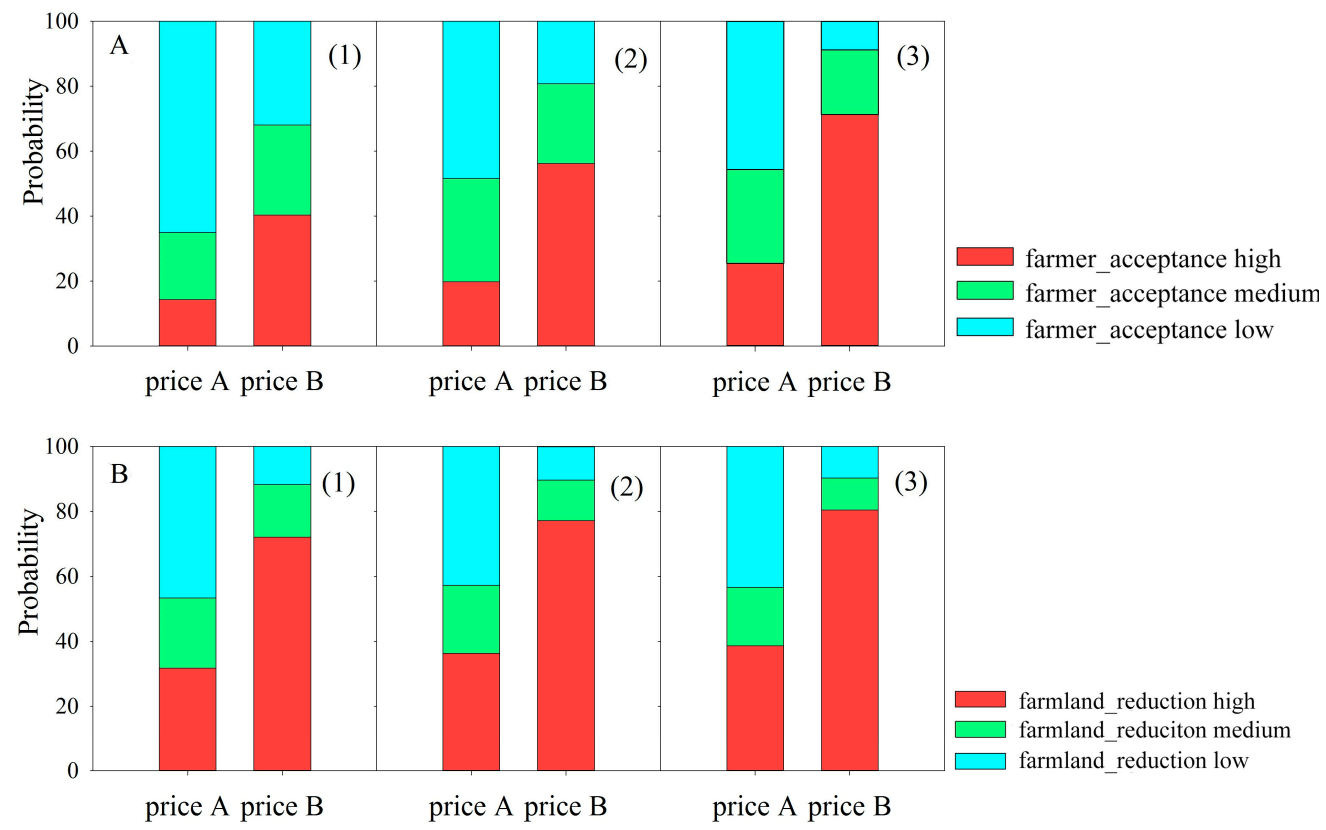

Figure 6. The impact of water-pricing policy based on an agricultural subsidy policy on farmers' planting behavior. (A,B) (1)-(3) respectively represent the degree of acceptance to abandon farmland and the reduction of arable land for farmers under different water pricing when GW mining fines are high and the agricultural subsidies are low, medium, and high, respectively.

\subsubsection{Impacts of Water Pricing on the ESV of Land (Scenario 4)}

Changes in land-use patterns may change land-cover conditions and affect regional ecological processes, which may cause variations in soil, water, and atmospheric conditions. Therefore, the ESV variable was introduced into the $\mathrm{BN}$ to study the effect of farmland abandonment due to increased water pricing on the value of land ecological services. According to Figure 7A,B, depending on the type of abandoned land converted from farmland to grassland and forest, the ESV increased by $31.4 \%$ and $38.6 \%$ under water price B compared with water price A. This result indicates that water-pricing policy can not only regulate farmers' planting behavior, it can also increase the ESV of the land.
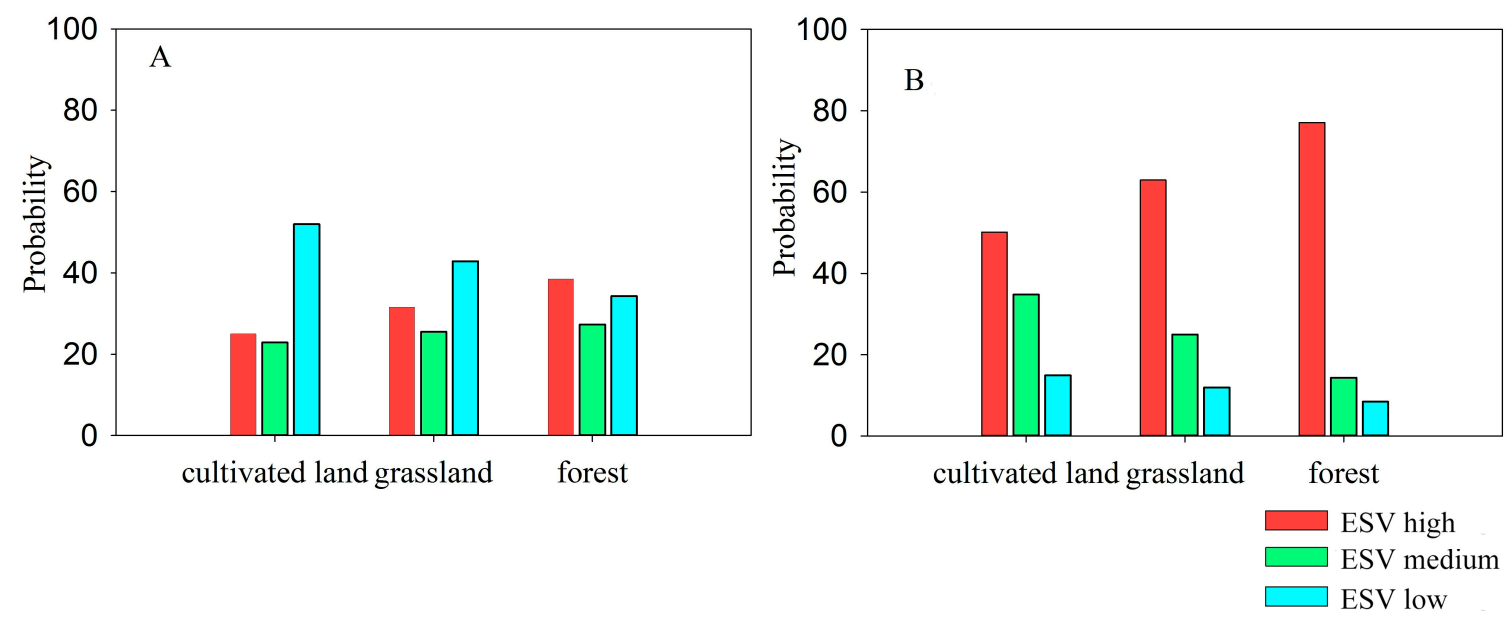

Figure 7. The impact of water pricing policy on the ESV of land. (A,B) respectively represent the ESV of converting farmland into different types of land use under different water pricing in the situation where the GW mining fine and agricultural subsidy is high. 


\section{Discussion}

Water resource management must consider not only the impact of policies on water resources, but also the social, economic, ecological, and environmental factors involved. To cope with the growing shortage of water resources, finding ways to maximize the effectiveness of the government's macro-control strategy and optimize the objective variables through multi-factor management is an issue that deserves in-depth study. Compared with traditional artificial neural networks and genetic algorithms, the BN can comprehensively consider conflicts among goals, conducting learning and bidirectional reasoning under limited and incomplete information to obtain the optimal solution [48,49]. In the meantime, as an economic water resource management measure, water pricing reflects the commercial nature and scarcity of water resources to some extent. Using the full-cost water-pricing model, on the one hand, can provide sufficient funds to enable water suppliers to recover water-supply costs and maintain the water-supply system in operation. On the other hand, farmers are encouraged to use advanced irrigation methods and techniques to reduce water waste [50]. Current research mainly uses linear dynamic mathematical planning models to simulate the behavior of farmers and their response to different water prices [51,52]. By combining the BN with water-pricing policies, stakeholders can be encouraged to participate in water resource management, facilitating water resource decision-making. The BN simulation results show that the water-saving effect of current water-pricing schemes is not obvious, and that farmers continue to show little willingness to reduce their cultivated land $[53,54]$.

The results of Scenario 1 show that under the current policy of low water prices, no significant water-saving effect can be achieved, and farmers have little willingness to abandon farmland and save water because the low water-price policy reduces the elasticity of farmer water demand $[55,56]$. The marginal benefits from agricultural planting activities are the main factors affecting farmer decision-making behavior. Only when the water price is increased to a point at which their planting income is significantly reduced do farmers start to reduce their consumption of water [57-59]. Using water-pricing policy will help farmers adjust their water-use behavior, but it will also decrease their income. Groundwater is an extremely important water resource in China, especially in the arid and semi-arid regions of the north, and groundwater mining and utilization has become more common in recent years [60]. Single increasing water prices may put GW preservation at risk. By introducing GW policy, the results of Scenario 2 show that the increasing the price of water could promote the adoption of water-saving technologies for farmers and protect GW safety. It also leads to an increased willingness of farmers to abandon their farmland. However, these behavioral changes may aggravate conflicts between government and farmers, and even cause policy failures due to the decline of farmer income [61,62]. From the result of Scenario 3, by introducing agricultural subsidy policies, governments can effectively avoid the negative externality effects caused by water-pricing policy while taking into account the profitability of farming [63-65]. At the same time, Scenario 4 shows that under the multi-policy conditions, although abandoning farmland caused the economic loss, it will increase the ESV of the land, because increasing the prices of water reduces the area of cultivated land and results in changes in land-use types [66].

Note that compared with saving irrigation water, the impact of increased water prices on farmers' income may be even more negative, which will reduce the willingness of farmers to plant [67]. In this study, reducing cultivated land is a goal that needs to be achieved, but for other regions, excessively high water prices may cause less crop production and limit rural socio-economic development. These impacts may increase the poverty gap between rural and urban areas, and result in a series of social problems. Such problems are something that policymakers do not want to see, and are also a point of controversy among Chinese and other water-pricing policy researchers [68,69]. Therefore, formulating a water-pricing scheme is a gradual process. Only by taking water pricing as the lead factor and assisting with multiple policies can water prices be adjusted according to water resource management principles to achieve the sustainable use of water resources. 


\section{Conclusions}

This paper proposes a new water resource management model for arid regions. By using the full-cost method and considering the value and environmental attributes of water resources to calculate water prices for basic farmland controlled by "the strictest water resource management measures", the basic water price was determined as $0.35 \mathrm{RMB} / \mathrm{m}^{3}$, and the irrigation water price outside the control of "the strictest water resource management measures" was determined as $1.4 \mathrm{RMB} / \mathrm{m}^{3}$. A BN model was introduced in this study to establish the relationship between water-pricing policy and farmers' planting behavior. Stakeholder participation and expert experience were used to determine key water resource management variables to analyze the impact of water-pricing policy from the standpoint of farmers' irrigation water-use methods, the degree of acceptance of the policy, and the willingness to reduce their cultivated land. The $\mathrm{BN}$ results show that the impact of water-pricing policy on the marginal income of farmers determines the policy effect. A rise in water prices leads to a decrease in farmers' income, forcing farmers to adjust their agricultural planting decisions and reduce their consumption of irrigation water. At the same time, to compensate for the negative externalities caused by water-pricing policy, the government must adopt GW control measures and agricultural subsidies to take charge of surface water and GW. According to the model simulation, the probabilities of reaching the government's goal of reducing cultivated land and increasing the ESV of land were $77.7 \%$ and $77.1 \%$, respectively. Therefore, in arid areas, the government should adopt a water resource management model led by water price and supplemented by GW and agricultural subsidy policies. This approach provides a new method and concept for developing countries, and even the world, to formulate policies for water resource management.

Author Contributions: This research was conducted by all authors. H.L. led the project and defined the research theme. X.Z. and G.Z. analyzed the data. H.X. and H.L. contributed to the discussion. X.Z. and H.L. wrote the paper.

Acknowledgments: This work was supported by the Main Service Project of Characteristic Institute of Chinese Academy of Sciences (TSS-2015-014-FW-2-2), the National Natural Science Foundation of China (41471099) and Youth Innovation Promotion Association Project (CAS) (2014389)

Conflicts of Interest: The authors declare no conflict of interest.

\section{References}

1. Vorusmarty, C.J.; Mcintyre, P.B.; Gessner, M.O.; Dudgeon, D.; Prusevich, A.; Green, P.; Glidden, S.; Bunn, S.E.; Sullivan, C.A.; Liermann, C.R.; et al. Global threats to human water security and river biodiversity. Nature 2010, 467, 555-561. [CrossRef] [PubMed]

2. Meybeck, M. Global analysis of river systems: From Earth system controls to Anthropocene syndromes. Philos. Trans. R. Soc. Lond. B Biol. Sci. 2003, 358, 1935-1955. [CrossRef] [PubMed]

3. Wang, K.Z.; Bin, L.I.; Quan, F.Y.U.; Jin, W.J. The Construction of Groundwater Reservoir and Its Beneficial Effect of Resource and Environment in Peninsula Shandong. J. Nat. Resour. 2008, 23, 575-580.

4. Kumar, M.D.; Singh, O.P. Market instruments for demand management in the face of scarcity and overuse of water in Gujarat, Western India. Water Policy 2001, 3, 387-403. [CrossRef]

5. Omer, A.M. Sustainable water resources management, future demands and adaptation strategies in Sudan. J. Environ. Sci. Water Resour. 2012, 1, 209-231.

6. Mejías, P.; Varela, O.C.; Flichman, G. Integrating agricultural policies and water policies under water supply and climate uncertainty. Water Resour. Res. 2004, 40, 289-302. [CrossRef]

7. Ren, D.; Yang, Y.; Yang, Y.; Richards, K.; Zhou, X. Land-Water-Food Nexus and indications of crop adjustment for water shortage solution. Sci. Total Environ. 2018, 626, 11-21. [CrossRef] [PubMed]

8. Hanjra, M.A.; Qureshi, M.E. Global water crisis and future food security in an era of climate change. Food Policy 2010, 35, 365-377. [CrossRef]

9. Deininger, K.; Byerlee, D.; Lindsay, J.; Norton, A.; Selod, H.; Sticker, M. Rising Global Interest in Farmland: Can It Yield Sustainable and Equitable Benefits? The World Bank: Washington DC, USA, 2011. 
10. Sun, M.Q.; Zhao, C.Y.; Shi, F.Z.; Peng, D.M.; Wu, S.X. Analysis on Land Use Change in the Mainstream Area of the Tarim River in Recent 20 Years. Arid Zone Res. 2013, 30, 16-21.

11. Seagraves, J.A.; Easter, K.W. Pricing Irrigation water in developing countries. J. Am. Water Resour. Assoc. 2010, 19, 663-672. [CrossRef]

12. Rogers, P.; Silva, R.D.; Bhatia, R. Water is an economic good: How to use prices to promote equity, efficiency, and sustainability. Water Policy 2002, 4, 1-17. [CrossRef]

13. Fakhraei, S.H.; Narayanan, R.; Hughes, T.C. Price Rigidity and Quantity Rationing Rules Under Stochastic Water Supply. Water Resour. Res. 1984, 20, 664-670. [CrossRef]

14. Ward, F.A.; Pulidovelazquez, M. Incentive pricing and cost recovery at the basin scale. Environ. Manag. 2009, 90, 293-313. [CrossRef] [PubMed]

15. Boland, J.J.; Whittington, D. The political economy of water tariff design in developing countries: Increasing block tariffs versus uniform price with rebate designs. In The Political Economy of Water Pricing Reforms; Dinae, A., Ed.; Oxford University Press: New York, NY, USA, 2000; pp. 215-236.

16. Johansson, R.C.; Tsur, Y.; Roe, T.L.; Doukkali, R.; Dinar, A. Pricing irrigation water: A review of theory and practice. J. Water Policy 2002, 4, 173-199. [CrossRef]

17. Varela, O.C.; Blanco, M.; Sumpsi, J.M. Integrating irrigation modernization programs and water pricing policies. Empirical evidence and water policy implications. In Proceedings of the XXIV International Congress of the IAAE, Berlin, Germany, 13-19 August 2000.

18. Li, Y.; Song, G.; Wu, Y.; Wan, W.; Zhang, M.; Xu, Y. Evaluation of water quality and protection strategies of water resources in arid-semiarid climates: A case study in the Yuxi River Valley of Northern Shaanxi Province, China. Environ. Geol. 2009, 57, 1933-1938.

19. Burmil, S.; Daniel, T.C.; Hetherington, J.D. Human values and perceptions of water in arid landscapes. Landsc. Urban Plan. 1999, 44, 99-109. [CrossRef]

20. Xian, W.; Xu, Z.; Deng, X. Agricultural irrigation water price based on full cost recovery: A case study in Ganzhou District of Zhangye Municipality. J. Glaciol. Geocryol. 2014, 36, 462-468.

21. Goldstein, J. Full-Cost Water Pricing. Am. Water Works Assoc. 1986, 78, 52-61. [CrossRef]

22. Kanakoudis, V.; Gonelas, K.; Tolikas, D. Basic principles for urban water value assessment and price setting towards its full cost recovery-pinpointing the role of the water losses. J. Water Supply 2011, 60, 27-39. [CrossRef]

23. Mann, P.C. Reform in Costing and Pricing Water. Am. Water Works Assoc. 1987, 79, 43-45. [CrossRef]

24. Kim, H.Y. Marginal cost and second-best pricing for water services. Rev. Ind. Organ. 1995, 10, $323-338$. [CrossRef]

25. Riesgo, L.; Gómez-Limón, J.A. Multi-criteria policy scenario analysis for public regulation of irrigated agriculture. Agric. Syst. 2007, 91, 1-28. [CrossRef]

26. Moore, M.R.; Gollehon, N.R.; Carey, M.B. Multicrop Production Decisions in Western Irrigated Agriculture: The Role of Water Price. Am. J. Agric. Econ. 1994, 76, 859-874. [CrossRef]

27. Dinar, A.; Subramanian, A. Water Pricing Experience; Technical Paper NO. 386; The World Bank: Washington, DC, USA, 1997.

28. Berbel, J.; Gómezlimón, J.A. The impact of water-pricing policy in Spain: An analysis of three irrigated areas. Agric. Water Manag. 2000, 43, 219-238. [CrossRef]

29. Giannoccaro, G.; Prosperi, M.; Zanni, G. Assessing the Impact of Alternative Water Pricing Schemes on Income Distribution. J. Agric. Econ. 2010, 61, 527-544. [CrossRef]

30. Rositano, F.; Ferraro, D.O. Ecosystem services provided by agroecosystems: A qualitative and quantitative assessment of this relationship in the Pampa region, Argentina. Environ. Manag. 2014, 53, 606-619. [CrossRef] [PubMed]

31. Grêtregamey, A.; Brunner, S.H.; Altwegg, J.; Bebi, P. Facing uncertainty in ecosystem services-based resource management. J. Environ. Manag. 2013, 127, 145-154. [CrossRef] [PubMed]

32. Richards, R.; Roiko, A.; Carter, R.W.; Bussey, M.; Matthews, J.; Smith, T.F. Bayesian belief modeling of climate change impacts for informing regional adaptation options. Environ. Model. Softw. 2013, 44, 113-121. [CrossRef]

33. Phan, T.D.; Smart, J.C.R.; Capon, S.J.; Hadwen, W.L.; Sahin, O. Applications of Bayesian belief networks in water resource management. Environ. Model. Softw. 2016, 85, 98-111. [CrossRef] 
34. Aguilera, P.A.; Fernández, A.; Fernández, R.; Rumí, R.; Salmerón, A. Bayesian networks in environmental modeling. Environ. Model. Softw. 2011, 26, 1376-1388. [CrossRef]

35. Wang, X.; Tan, X.; Chen, Y. Study on Construction of Full Cost Water Pricing Model. Water Resour. Power 2011, 5, 034 .

36. Pearl, J. Probabilistic reasoning in intelligent systems: Networks of plausible inference. Comput. Sci. Artif. Intell. 1988, 70, 1022-1027.

37. Marchette, D.J. Bayesian Networks and Decision Graphs. Technometrics 2008, 45, 178-179. [CrossRef]

38. Mccann, R.K.; Marcot, B.G.; Ellis, R. Bayesian belief networks: Applications in ecology and natural resource management. Can. J. For. Res. 2006, 36, 3053-3062. [CrossRef]

39. Bromley, J. Guidelines for the Use of Bayesian Networks as a Participatory Tool for Water Resource Management; Centre for Ecology and Hydrology: Bailrigg, UK, 2005.

40. Fienen, M.N.; Plant, N.G. A cross-validation package driving Netica with python. Environ. Model. Softw. 2015, 63, 14-23. [CrossRef]

41. Fienen, M.N.; Masterson, J.P.; Plant, N.G.; Gutierrez, B.T.; Thieler, E.R. Bridging groundwater models and decision support with a Bayesian network. Water Resour. Res. 2013, 49, 6459-6473. [CrossRef]

42. Marcot, B.G. Metrics for evaluating performance and uncertainty of Bayesian network models. Ecol. Model. 2012, 230, 50-62. [CrossRef]

43. Qiong, M.A.; Wang, Y. Evaluating the externally environmental cost of cotton production in Xinjiang. J. Arid Land Resour. Environ. 2015, 29, 63-68.

44. Marcot, B.G.; Steventon, J.D.; Sutherland, G.D.; McCann, R.K. Guidelines for developing and updating Bayesian belief networks applied to ecological modeling and conservation. Can. J. For. Res. 2006, 36, 3063-3074. [CrossRef]

45. Cain, J. Planning Improvements in Natural Resources Management. Encycl. Inf. Syst. 2001, 15, $239-265$.

46. Castelletti, A.; Soncini, S.R. Bayesian Networks and Participatory Modelling in Water Resource Management; Elsevier Science Publishers: Amsterdam, The Netherlands, 2007.

47. Alameddine, I.; Cha, Y.K.; Reckhow, K.H. An evaluation of automated structure learning with Bayesian networks: An application to estuarine chlorophyll dynamics. Environ. Model. Softw. 2011, 26, 163-172. [CrossRef]

48. Barton, D.N.; Kuikka, S.; Varis, O.; Uusitalo, L.; Henriksen, H.J.; Borsuk, M.; de la Hera, A.; Farmani, R.; Johnson, S.; Linnell, J.D. Bayesian networks in environmental and resource management. Integr. Environ. Assess. Manag. 2012, 8, 418-429. [CrossRef] [PubMed]

49. Chan, T.U.; Hart, B.T.; Kennard, M.J.; Pusey, B.J.; Shenton, W.; Douglas, M.M.; Valentine, E.; Patel, S. Bayesian network models for environmental flow decision making in the Daly River, Northern Territory, Australia. River Res. Appl. 2010, 28, 283-301. [CrossRef]

50. Henri, T.; Bernard, P. Full cost or "sustainability cost" pricing in irrigated agriculture. Charging for water can be effective, but is it sufficient? Irrig. Drain. 2002, 51, 97-107.

51. Sumpsi, J.M.; Amador, F.; Romero, C. On Farmer's Objectives: A multi-criteria Approach. Eur. J. Oper. Res. 1997, 96, 64-71. [CrossRef]

52. Varela-Ortega, C.; Sumpsi, J.M.; Garrido, A.; Blanco, M.; Iglesias, E. Water Pricing Policies, Public Decision Making and Farmers' Response: Implications for Water Policy. Agric. Econ. 1998, 19, 193-202. [CrossRef]

53. Mohajerani, H.; Kholghi, M.; Mosaedi, A.; Farmani, R.; Sadoddin, A.; Casper, M. Application of Bayesian Decision Networks for Groundwater Resources Management Under the Conditions of High Uncertainty and Data Scarcity. Water Resour. Manag. 2017, 31, 1859-1879. [CrossRef]

54. Pollino, C.A.; Woodberry, O.; Nicholson, A.; Korb, K.; Hart, B.T. Parameterisation and evaluation of a Bayesian network for use in an ecological risk assessment. Environ. Model. Softw. 2007, 22, 1140-1152. [CrossRef]

55. Howitt, R.E.; Watson, W.D.; Adams, R.M. A reevaluation of price elasticities for irrigation water. Water Resour. Res. 1980, 16, 623-628. [CrossRef]

56. Scheierling, S.M.; Loomis, J.B.; Young, R.A. Irrigation water demand: A meta-analysis of price elasticities. Water Resour. Res. 2006, 42, 85-88. [CrossRef]

57. Bazzani, G.M.; Pasquale, S.D.; Gallerani, V.; Morganti, S.; Raggi, M.; Viaggi, D. The sustainability of irrigated agricultural systems under the Water Framework Directive: First results. Environ. Model. Softw. 2005, 20, 165-175. [CrossRef] 
58. Gómez-Limón, J.A.; Riesgo, L. Irrigation water pricing: Differential impacts on irrigated farms. Agric. Econ. 2004, 31, 47-66. [CrossRef]

59. Amir, I.; Fisher, F.M. Response of near-optimal agricultural production to water policies. Agric. Syst. 2000, 64, 115-130. [CrossRef]

60. Deng, M.J. Current situation and its potential analysis of exploration and utilization of groundwater resources of Xinjiang. Arid Land Geogr. 2009, 32, 647-654.

61. Liao, Y.; Giordano, M.; Fraiture, C.D. An empirical analysis of the impacts of irrigation pricing reforms in China. Water Policy 2007, 9, 45-60. [CrossRef]

62. Venot, J.P.; Molle, F. Groundwater Depletion in the Jordan Highlands: Can Pricing Policies Regulate Irrigation Water Use? Water Resour. Manag. 2008, 22, 1925-1941. [CrossRef]

63. Medellín, A.J.; Howitt, R.E.; Harou, J.J. Predicting farmer responses to water pricing, rationing and subsidies assuming profit maximizing investment in irrigation technology. Agric. Water Manag. 2012, 108, 73-82. [CrossRef]

64. Toan, T.D. Water Pricing Policy and Subsidies to Irrigation: A Review. Environ. Process. 2016, 3, 1-18. [CrossRef]

65. Gómez-Limón, J.A.; Arriaza, M.; Berbel, J. Conflicting Implementation of Agricultural and Water Policies in Irrigated Areas in the EU. J. Agric. Econ. 2010, 53, 259-281. [CrossRef]

66. Tian, Y.W.; Huang, Z.L.; Xiao, W.F. Effects of Conversion Cropland to Forest on Values of Ecosystem Services Based on RS and GIS in Heigou Watershed of Three Gorges Reservoir Area. Res. Soil Water Conserv. 2010, 17, 97-100.

67. Gaudin, S. Effect of price information on residential water demand. Appl. Econom. 2006, 38, 383-393. [CrossRef]

68. Kim, C.S.; Schaible, G.D. Economic Benefits Resulting From Irrigation Water Use: Theory and an Application to Groundwater Use. Environ. Resour. Econ. 2000, 17, 73-87. [CrossRef]

69. Perry, C.J. Charging for Irrigation Water: The Issues and Options, with a Case Study from Iran; International Water Management Institute: Colombo, Sri Lanka, 2001.

(c) 2018 by the authors. Licensee MDPI, Basel, Switzerland. This article is an open access article distributed under the terms and conditions of the Creative Commons Attribution (CC BY) license (http:/ / creativecommons.org/licenses/by/4.0/). 